\title{
Eastern Filbert Blight Resistance in American and Interspecific Hybrid Hazelnuts
}

\author{
Ronald S. Revord and Sarah T. Lovell \\ Department of Crop Sciences, Institute for Sustainability, Energy, and Environment, Plant Science \\ Lab, University of Illinois at Urbana-Champaign, 1201 S. Dorner Drive, Urbana, IL 61801
}

John M. Capik

Department of Plant Biology, Foran Hall, 59 Dudley Road, Rutgers University, New Brunswick, NJ 08901

\author{
Shawn A. Mehlenbacher \\ Department of Horticulture, Oregon State University, 4017 Ag and Life Sciences Building, Corvallis, \\ OR 97331 \\ Thomas J. Molnar \\ Department of Plant Biology, Foran Hall, 59 Dudley Road, Rutgers University, New Brunswick, NJ \\ 08901
}

\begin{abstract}
AdDitional IndeX words. Anisogramma anomala, disease resistance, germplasm, tree breeding
ABstract. Eastern filbert blight (EFB), caused by the fungus Anisogramma anomala, is a primary limitation to european hazelnut (Corylus avellana) cultivation in eastern North America. American hazelnut (Corylus americana) is the endemic host of $A$. anomala and, despite its tiny, thick-shelled nuts, is a potentially valuable source of EFB resistance and climatic adaptation. Interspecific hybrids (Corylus americana $\times$. avellana) have been explored for nearly a century as a means to combine EFB resistance with wider adaptability and larger nuts. Although significant progress was made in the past, the genetic diversity of the starting material was limited and additional improvements are needed for expansion of hazelnut (Corylus sp.) production outside of Oregon, where $99 \%$ of the U.S. crop is currently produced. Our objective was to determine if $C$. americana can be a donor of EFB resistance. We crossed 29 diverse EFB-resistant $C$. americana accessions to EFB-susceptible $C$. avellana selections (31 total progenies) to produce $2031 \mathrm{~F}_{1}$ plants. In addition, new $C$. americana germplasm was procured from across the native range of the species. The new collection of 1335 plants from 122 seed lots represents 72 counties and 22 states. The interspecific hybrid progenies and a subset of the American collection (616 trees from 62 seed lots) were field planted and evaluated for EFB response following field inoculations and natural disease spread over seven growing seasons. EFB was rated on a scale of 0 (no EFB) to 5 (all stems containing cankers). Results showed that progeny means of the interspecific hybrids ranged from 0.96 to 4.72 . Fourteen of the 31 progenies were composed of at least one-third EFB-free or highly tolerant offspring (i.e., ratings 0-2), transmitting a significant level of resistance/tolerance. Several corresponding $C$. americana accessions that imparted a greater degree of resistance to their hybrid offspring were also identified. In addition, results showed that $587(95.3 \%)$ of the 616 C. americana plants evaluated remained completely free of EFB. These findings confirm reports that the species rarely expresses signs or symptoms of the disease and should be robustly studied and exploited in breeding.
\end{abstract}

Hazelnut (Corylus sp.) includes 13 polymorphic deciduous shrub and tree species that bear edible nuts (Bassil et al., 2013; Erdogan and Mehlenbacher, 2000a). The genus demonstrates wide morphological diversity and adaptability, with species inhabiting forests throughout the northern hemisphere (Mehlenbacher, 1991; Molnar, 2011). Current cultivation depends almost entirely on european hazelnut (C. avellana) and is restricted to Mediterranean-like climates that allow consistent yields. The scale of global hazelnut production closely mirrors that of pistachio (Pistacia vera) at $\approx 1$ million tonnes of annual inshell production (Food and Agriculture Organization of the United Nations, 2017), and its market is experiencing steady growth (Technavio, 2017). Production in the United States occurs pri-

Received for publication 1 May 2019. Accepted for publication 6 Jan. 2020. Published online 9 April 2020.

T.J.M. is the corresponding author. E-mail: molnar@aesop.rutgers.edu.

This is an open access article distributed under the CC BY-NC-ND license (https://creativecommons.org/licenses/by-nc-nd/4.0/). marily in the Willamette Valley of Oregon [U.S. Department of Agriculture (USDA), 2018], which produces $\approx 5 \%$ of the global supply. There is considerable interest in expanding cultivation to other regions in the United States and Canada (Fischbach, 2017; Molnar and Capik, 2012a).

Climatic suitability and the broad presence of EFB limit the cultivation of european hazelnut in the eastern and midwestern United States (Thompson et al., 1996). The causal organism of EFB is Anisogramma anomala, an obligate biotrophic ascomycete that is endemic to eastern North America (Johnson and Pinkerton, 2002). In nature, $A$. anomala coexists with american hazelnut ( $C$. americana), occasionally producing minor, inconsequential stem cankers (Capik and Molnar, 2012; Fuller, 1908; Weschcke, 1953). Conversely, infection of $C$. avellana results in severe, perennial stem cankers that lead to branch dieback, yield decline, and in many cases plant death (Johnson and Pinkerton, 2002). C. americana is native to much of North America east of the Rocky Mountains, extending from Maine to 
northern Florida in the east, over to its western boundary that extends from eastern Oklahoma to North Dakota and southern Manitoba (Drumke, 1964; Gleason and Cronquist, 1963). This extensive geography suggests that $C$. americana may represent a diverse source of resistance and tolerance to EFB, and moreover, a source of adaptation to a spectrum of soil types and climatic zones that nearly span the latitudinal range of the United States.

Thus, if systematically exploited for breeding interspecific hybrids, C. americana may enable the expansion of commercial hybrid hazelnut production to a wide portion of the eastern and midwestern United States (Molnar, 2011; Molnar et al., 2005). Unfortunately, the plant architecture and nuts of $C$. americana are not well-suited for commercial production and existing markets. The shrubby architecture and aggressive production of basal sprouts by $C$. americana also present challenges for maintaining the desired single-stemmed form found in modern european hazelnut orchards. Compared with those of $C$. avellana cultivars, the nuts of $C$. americana are very small and enclosed in thick, clasping involucres, which complicates harvest. Further, the shells tend to be very thick. Nevertheless, C. americana and C. avellana can be crossed in either direction, and the resulting hybrids are viable and fertile (Erdogan and Mehlenbacher, 2000b). Past breeders have noted the potential for continued improvement, with the recovery of most $C$. avellana traits in selected individuals of the first or second backcross generation following interspecific hybridization (Molnar, 2011; Molnar et al., 2018).

Attempts have been made to develop interspecific hybrids since the early 20th century (reviewed in Molnar, 2011; Molnar and Capik, 2012b). In 1919, J.F Jones of Lancaster, PA, made the first reported $C$. americana $\times C$. avellana $\mathrm{F}_{1}$ hybrids using the wild selection 'Rush' as the $C$. americana parent crossed with a number of $C$. avellana cultivars. Compared with other $C$. americana, 'Rush' appeared to be better adapted and produced higher yields of larger nuts, and continued to be used as parent by C.A. Reed of the Bureau of Plant Industry, USDA in Beltsville, MD, and G.H. Slate of the New York State Agricultural Experiment Station in Geneva, NY. From 1928 to 1930 , Reed and Slate each produced $\approx 2000 \mathrm{~F}_{1}$ hybrids from crosses of 'Rush' as the female parent with pollen of several $C$. avellana cultivars, and then oversaw their long-term evaluation.

S.H. Graham of Ithaca, NY, also built on Jones' work, evaluating seedlings derived from open-pollinated 'Rush' $F_{1}$ hybrids. In addition, Graham made controlled crosses with a wild $C$. americana selection from Iowa called 'Winkler'. Unfortunately, much of Graham's materials were eventually lost to EFB.

Throughout the 1930s and 1940s, Carl Weschcke of River Falls, WI, also used 'Winkler' to develop many interspecific hybrids. Over time, fatal EFB infections spread throughout most of Weschcke's progenies and no cultivars were released, although there were some survivors (Weschcke, 1953, 1963). Later, seeds from select, EFB-resistant individuals that remained in Weschcke's infected plantings were collected by Philip Rutter of Canton, MN, to begin a mass selection program. Rutter subsequently supplemented his population with other wild selections and improved hybrid germplasm, including plants derived from 'Rush'. From this work, populations were developed that expressed EFB resistance, cold hardiness, and improved nut traits (Rutter, 1987). Seedlings from this population have been disseminated widely throughout the upper midwest, where $\approx 130$ growers have more than 30,000 shrubs in production (Demchik et al., 2011). The Arbor Day Foundation (ADF, Nebraska City, NE) established 5000 seedlings purchased from Rutter in 1996, and from this planting several consistently high-yielding, EFB-resistant selections have been identified (Capik and Molnar, 2012; Hammond, 2006). Additional clonal selections are under replicated evaluation across Wisconsin and Minnesota by the Upper Midwest Hazelnut Development Initiative (Braun et al., 2018).

Each of the aforementioned efforts identified EFB-resistant hybrids with improved commercial traits, and Oregon State University (OSU) and the USDA-Agriculture Research Service (ARS)-National Clonal Germplasm Repository (NCGR) in Corvallis, OR, have conserved a number of these selections for future use. However, although thousands of seedlings and several clonal selections have been sold and distributed by nurseries, none from this early work has supported commercialscale planting to date. In addition, these interspecific hybrids were developed from a small number of parents and represent a relatively narrow genetic base. Sathuvalli and Mehlenbacher (2012) characterized 67 C. americana $\times C$. avellana hybrids jointly held by the NCGR, OSU, and the ADF using microsatellite markers in comparison with a collection of 87 pure $C$. americana, and found nearly all of the hybrid accessions clustered with either 'Rush' or 'Winkler' and the Weschcke hybrid group. Although levels of diversity were similarly high in these interspecific hybrid groups and wild $C$. americana, the interspecific hybrids had fewer alleles at the microsatellite marker loci (Sathuvalli and Mehlenbacher, 2012). Moreover, these early reports presented few data on the inheritance of EFB resistance, but their records mention instances in which large seedling populations were almost entirely lost to EFB (Rutter, 1991; Slate, 1969). The absence of systematic studies and a poor understanding of the inheritance of EFB resistance from $C$. americana is a challenge for reaching breeding objectives, which expand beyond disease resistance and include kernel traits, yield, and climatic adaptation.

Several recent studies have begun to shed light on the inheritance of EFB resistance from $C$. americana. Molnar and Capik (2012b) reported that three 'Rush'-related progenies segregated in a ratio of 1 resistant: 1 susceptible, indicating a dominant allele at a single locus. Bhattarai et al. (2017a) confirmed this mode of inheritance from 'Rush' and the closely related hybrid 'Yoder \#5', and placed the resistance locus on linkage group 7. Molnar and Capik (2012b) reported segregation data from biparental crosses between eight $C$. americana $\times$ C. avellana hybrids of Rutter origin and susceptible $C$. avellana. Little to no resistance or tolerance was recovered in seven of these progenies, which was surprising, as five of the hybrid parents had been completely resistant to EFB at the experimental site. In the eighth progeny, however, $\approx 50 \%$ of the seedlings were rated tolerant and $15 \%$ were free of disease. A similar response pattern was observed in three of the six progenies derived from wild $C$. americana crossed to susceptible $C$. avellana, whereas seedlings in the other three showed little tolerance (Molnar and Capik, 2012b). These studies and the results of past breeding efforts demonstrate that EFB resistance from $C$. americana can be accessed through interspecific hybridization. However, the species transmits resistance to its interspecific offspring variably, with both major and minor genes for resistance and tolerance likely 
present in the germplasm pool. Furthermore, the disease response of the $C$. americana parent may not indicate its ability to transmit resistance or tolerance to its progeny.

The current collections of the USD-ARS-NCGR and OSU contain a total of $\approx 80 C$. americana accessions. These accessions were derived primarily from wild seed procured by S.A. Mehlenbacher in the late 1980s with help from members of the Northern Nut Growers Association (NNGA). From among several hundred seedlings, selections were made based on geographic origin, nut characteristics, and a reduced tendency to biennial bearing. Based on genetic characterization of the collection using microsatellite markers, Sathuvalli and Mehlenbacher (2012) described these accessions as highly diverse and valuable as initial germplasm for breeding. However, given the extensive native range of $C$. americana, this collection does not represent the full extent of the genetic and trait diversity present within the species, and further collection is warranted.

The lack of understanding regarding the transmission of EFB resistance combined with poor nut quality and other negative production traits of $C$. americana complicates the process of developing hybrid cultivars that are competitive with $C$. avellana with respect to nut quality. Fortunately, intraspecific hybridization became a viable strategy for developing disease-resistant cultivars following the identification of EFBresistant C. avellana 'Gasaway' in the 1970s, which was found to be heterozygous for a dominant allele at a single resistance locus (Mehlenbacher et al., 1991). Although 'Gasaway', an obsolete late-shedding pollenizer, has many horticultural deficiencies, it was subsequently used to develop several EFB-resistant cultivars (Santiam, Yamhill, Jefferson, Dorris, Wepster, and McDonald) (Mehlenbacher, 2018; Mehlenbacher et al., 2007, 2009, 2011, 2013, 2014, 2016). These cultivars have supported a landmark expansion of the Oregon hazelnut industry, which grew from 11,700 ha to greater than 31,000 ha from 2009 to 2018 (N.G. Wiman, personal communication).

Concerns over the long-term durability of a single source of resistance as well as potential pathogen diversity led breeders to concurrently assemble and screen vast germplasm collections for EFB response. Initial screens of collected germplasm identified additional sources of resistance (Chen et al., 2007; Coyne et al., 1998; Lunde et al., 2000), and linkage mapping confirmed monogenic resistance from multiple sources [e.g., 'Ratoli' and 'Culplà' from Spain, OSU 759.010 from Georgia, OSU 495.027 from Russia, OSU 408.040 from Minnesota, 'Crvenje' and 'Uebov' from Serbia (Bhattarai et al., 2017b; Chen et al., 2005; Colburn et al., 2015; Sathuvalli et al., 2011a, 2011b)]. Resistance was mapped to three different linkage groups (LGs), although most sources map to a cluster on LG 6 in the region near the 'Gasaway' $R$ gene (Sathuvalli et al., 2014). These selections are now being used by OSU and Rutgers University in further breeding and gene pyramiding schemes in an attempt to improve the durability of resistance (Molnar et al., 2018; Sathuvalli et al., 2014).

Continued screening efforts by both OSU and Rutgers University have identified EFB-resistant $C$. avellana from Estonia, Latvia, Lithuania, Poland, Russia, Crimea, Georgia, Moldova, and Turkey (Capik and Molnar, 2012; Capik et al., 2013; Leadbetter et al., 2016; Molnar et al., 2007, 2018; Muehlbauer et al., 2014). The continued discovery of EFB resistance in $C$. americana is additive to the work previously completed for $C$. avellana and may expand, through interspecific hybridization, potential for enhanced climatic adaptability to the more severe summer and winter conditions of the midwest United States.
In this study, a diverse collection of 29 C. americana accessions were evaluated as donor parents of EFB resistance in interspecific hybridization with EFB-susceptible C. avellana. In addition, an extensive new $C$. americana germplasm collection was assembled to expand the genetic base of the material available for breeding. The $\mathrm{F}_{1}$ hybrids and new $C$. americana plant materials were established in the field in New Jersey, exposed to high EFB pressure, and assessed for their response to disease after seven growing seasons.

\section{Materials and Methods}

\section{Plant materials and culture}

C. americana $\times$ C. aVellana $\mathrm{F}_{1}$ Progenies. Twenty-nine $C$. americana accessions were crossed with EFB-susceptible $C$. avellana to examine transmission of resistance to their $F_{1}$ offspring (Table 1). Crosses were made in 2009 to 2011 following methods described in Mehlenbacher (1994). Twelve interspecific crosses were made at Rutgers University and the remainder at OSU. A total of 2031 plants representing 31 different progenies were evaluated in the field. The $C$. americana parents originated from the seed collection made by S.A. Mehlenbacher (described earlier) and are held in the collections at OSU and the USDA-ARS-NCGR, with a subset of grafted trees held at Rutgers University. Twenty-two of the 29 C. americana parents were evaluated and rated free of disease in New Jersey [as noted in Table 1 (Capik and Molnar, 2012)], with the remaining parents only tested in Oregon, where they have shown no signs or symptoms of EFB (S.A. Mehlenbacher, unpublished data). The $C$. avellana parents were selected based on their known susceptibility to EFB and improved nut and kernel characteristics with the aim of producing $F_{1}$ offspring that would segregate for disease response as well as improved production traits. One $C$. avellana $\times C$. avellana cross was included as a control (OSU 11041) and was expected to segregate for quantitative resistance/tolerance.

The resulting hybrid seeds were collected in mid-August of each year and kept in cold storage until October when they were placed in moist peatmoss and stratified at $4{ }^{\circ} \mathrm{C}$ until March of the following year. Seeds were germinated in the greenhouse (24/ $18^{\circ} \mathrm{C}$ day/night with 16 -h daylength) in wooden planting boxes $(61 \times 91 \times 15 \mathrm{~cm})$ containing a peat-based medium. The seedlings were transplanted after 6 weeks into 2.8 -L containers using the same media and top-dressed with $5 \mathrm{~g}$ of $15 \mathrm{~N}-3.9 \mathrm{P}-10 \mathrm{~K}$ slowrelease fertilizer with micronutrients [5 to 6 months (Osmocote Plus; ICL Specialty Fertilizers, Summerville, SC)]. Plants were moved outdoors in late May for acclimation under shadecloth (40\% shade) until field planting in October of the same year. Tree spacing was $\approx 1.0 \mathrm{~m}$ within the row by $\approx 3.5 \mathrm{~m}$ between rows. Plants from each progeny were planted consecutively in rows at the Rutgers University Horticultural Farm 1 in New Brunswick, NJ, and the Cream Ridge Fruit Research and Extension Station, Cream Ridge, NJ. Weed control, irrigation, and fertilizer were provided as needed, but no chemical control of pests or diseases was applied. The seedling bushes were not pruned.

C. AMERICANA GERMPLASM. A total of 1335 C. americana seedlings from 122 seed lots representing 22 states and 72 counties was procured. The collection effort was initiated and assembled through the help of partners, colleagues, and the interested public, especially members of NNGA and ADF (Molnar et al., 2018). Open-pollinated seed was obtained from many locations across the native range of the species and sent to Rutgers for germination and subsequent field planting. The 
Table 1. Parentage of Corylus americana $\times$ Corylus avellana progeny rated for eastern filbert blight (EFB) disease in New Jersey.

\begin{tabular}{|c|c|}
\hline Progeny no. ${ }^{\mathrm{z}}$ & Parentage $^{\mathrm{y}, \mathrm{x}}$ \\
\hline OSU 09041 & OSU 403.028 (C. americana Nebraska, PI 87145) $\times$ OSU Mix A 2009w \\
\hline OSU 09044 & OSU 533.069v (C. americana Pennsylvania) $\times$ OSU Mix B 2009 \\
\hline OSU 09046 & OSU 557.102 (C. americana Wisconsin) $\times$ OSU Mix B 2009 \\
\hline OSU 09047 & OSU $557.125^{\mathrm{v}}$ (C. americana Wisconsin) $\times$ OSU Mix A 2009 \\
\hline OSU 10052 & OSU $405.038^{\mathrm{v}}$ (C. americana New Jersey) $\times$ OSU Mix $2010^{\mathrm{v}}$ \\
\hline OSU 10059 & C. avellana 'Clark' $\times$ OSU 405.006 (C. americana Pennsylvania) \\
\hline OSU $11041^{\mathrm{u}}$ & OSU $1197.113($ (C. avellana) $\times$ OSU 1155.009 (C. avellana) \\
\hline OSU 11050 & OSU $405.043^{\mathrm{v}}$ (C. americana New Jersey) $\times$ OSU Mix 2011 \\
\hline OSU 11051 & OSU 532.082 (C. americana Michigan) $\times$ OSU Mix 2011 \\
\hline OSU 11052 & OSU 588.044 (C. americana Illinois) $\times$ OSU Mix 2011 \\
\hline OSU 11053 & CCOR 857 (C. americana Illinois) $\times$ OSU Mix 2011 \\
\hline OSU 11061 & C. avellana 'Clark' $\times$ CCOR $59.001^{\mathrm{v}}$ (C. americana Mississippi) (PI 433984) \\
\hline OSU 11062 & C. avellana 'Clark' × CCOR 847 (C. americana Illinois) (PI 641150) \\
\hline Rutgers 11525 & OSU $403.040^{\mathrm{v}}($ C. americana Nebraska $) \times C$. avellana 'Tonda di Giffoni' \\
\hline Rutgers 11529 & OSU $557.125^{\mathrm{v}}$ (C. americana Wisconsin $) \times C$. avellana 'Tonda di Giffoni' \\
\hline Rutgers 11530 & OSU 533.069" (C. americana Pennsylvania) $\times C$. avellana 'Tonda di Giffoni' \\
\hline Rutgers 11533 & $\begin{array}{l}\text { OSU } 366.060^{v}(C \text {. americana Mississippi) (CCOR 59.002, PI 433984) } \times \text { C. avellana 'Tonda } \\
\text { Gentile delle Langhe' (PI 557035, CCOR 31.001) }\end{array}$ \\
\hline Rutgers 11534 & OSU $557.026^{v}(C$. americana Virginia) $\times$ C. avellana 'Tonda Gentile delle Langhe' \\
\hline Rutgers 11535 & OSU $531.027^{\vee}$ (C. americana Indiana) $\times$ C. avellana 'Tonda Romana' \\
\hline Rutgers 11540 & OSU 557.122v (C. americana Wisconsin) (CCOR 710.001, PI 617273) $\times$ C. avellana 'Tonda di Giffoni' \\
\hline Rutgers 11541 & OSU 531.043 (C. americana North Dakota) (CCOR 677.001, PI 617244) $\times$ C. avellana 'Tonda di Giffoni' \\
\hline
\end{tabular}

${ }^{\bar{z}}$ Oregon State University (OSU), Corvallis, OR; Rutgers University, New Brunswick, NJ; Controlled crosses were made in the year indicated by the first two digits of the progeny identification number.

${ }^{\mathrm{y}}(C$. americana State) denotes the U.S. state in which seeds of the $C$. americana parent were collected.

${ }^{x}$ The OSU selection ID number (i.e., OSU 403.028) represents the location (row.tree) at the OSU Smith Horticulture Research Farm, Corvallis, OR; PI is the Plant Inventory number of the accession in the USDA-Agriculture Research Service-National Clonal Germplasm Repository (USDA-ARS-NCGR) collection; CCOR is local inventory number of the accession in the USDA-ARS-NCGR collection.

${ }^{\mathrm{w}}$ C. avellana pollen mixtures were composed of three OSU EFB-susceptible breeding selections to ensure compatibility with the $C$. americana accessions that at the time carried unknown (S) alleles. The 2009A pollen mixture consisted of one-third each of the following selections (S alleles are listed with the dominant allele underlined): 'Sacajawea' ( 122$)$, OSU 786.091 ( $2 \underline{4}$ 4), and OSU 806.051 ( $\underline{8} 19)$. The 2009B pollen mixture consisted of one-third each of the following selections: OSU 1039.010 (15 21), OSU 1051.038 (2 14), and OSU 1033.068 (4 8). The 2010 pollen mixture consisted of one-third each of the following selections: OSU 995.042 (2 3), OSU $1156.105(\underline{8} 10)$ and OSU $1158.109(22$ 25). The 2011 pollen mixture consisted of one-third each of the following selections: OSU 1156.105 ( $\underline{8} 10)$, OSU 1213.038 (1 2 ), and OSU 1224.065 (12 22).

${ }^{\mathrm{v}}$ C. americana parents were rated as free of EFB in New Jersey (Capik and Molnar 2012). Other selections have not been tested in New Jersey but remain free of EFB in Oregon.

${ }^{\mathrm{u}} \mathrm{A}$ pure $C$. avellana $\times$ C. avellana control segregating for quantitative resistance. OSU 1197.113 has quantitative resistance. OSU 1155.009 is susceptible.

collection locations closely reflect the native range of the species (Fig. 1). A subset of the C. americana collection that included 616 bushes from 62 seed lots was evaluated in this study. This subset included all bushes of the collection that had been under long-term disease pressure for 6 years or more and thus clearly expressed mature disease phenotypes. These were trees from seeds obtained before 2011, which were planted at the Cream Ridge Fruit Research and Extension Station in 2012 under conditions similar to those described previously for the interspecific hybrid seedlings in rows adjacent to most of them, thus providing a direct basis for comparison.

\section{Exposure to EFB}

All interspecific hybrid seedlings and the subset of $C$. americana germplasm were exposed to EFB through field inoculations. Hazelnut stems harboring EFB stromata were tied into the canopy of every fifth tree in April at the time of leaf budbreak for the first 3 years following planting (Molnar et al., 2007). The hazelnut stems 


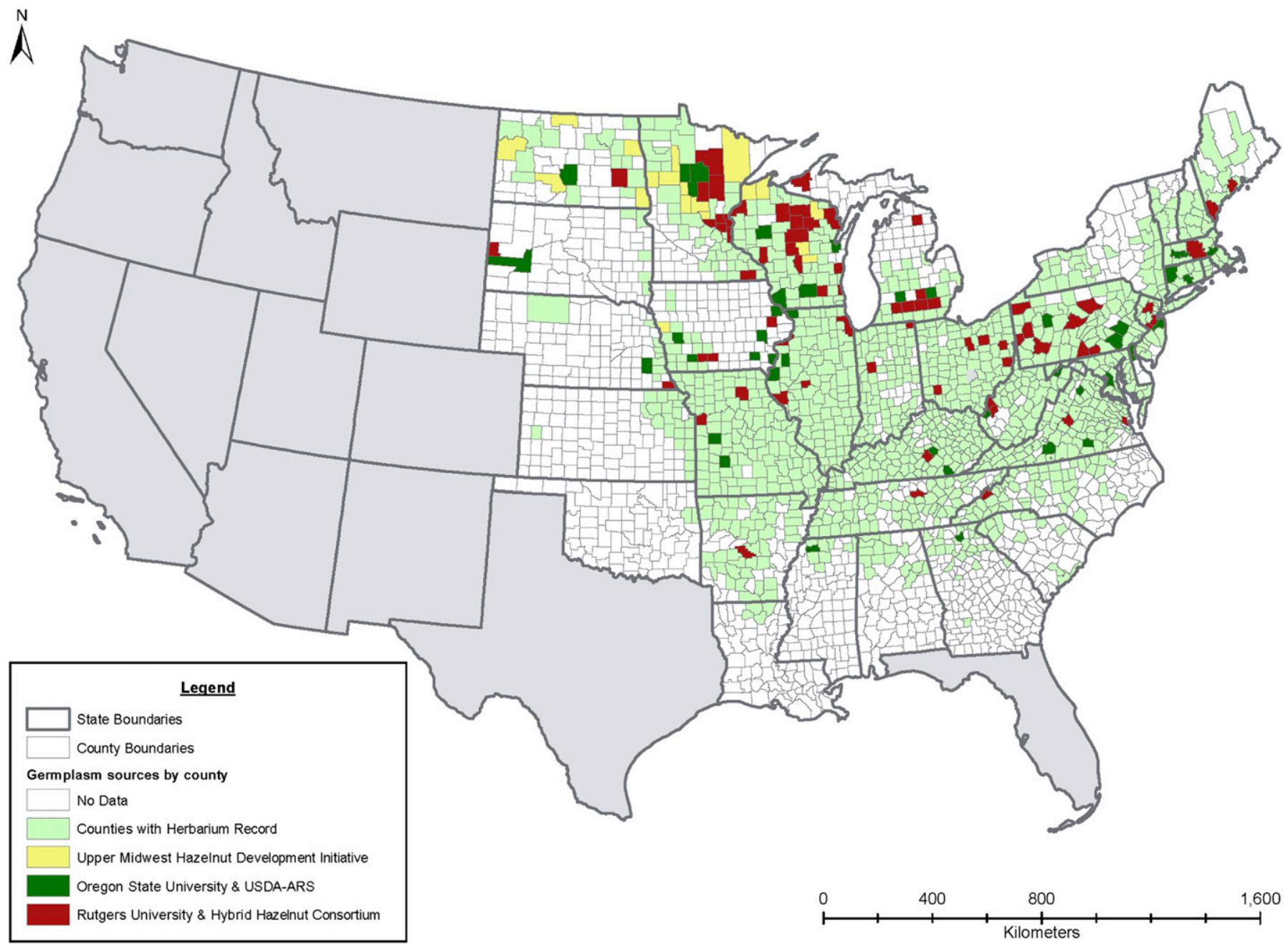

Fig. 1. A geographic information systems map depicting the native distribution of Corylus americana and the distribution of the existing university and U.S. Department of Agriculture (USDA)-Agriculture Research Service-National Clonal Germplasm Repository collections. Herbarium records compiled from the USDA are shown in light green. Collection sites of the Upper Midwest Hazelnut Development Initiative (Demchik et al., 2018) are shown in yellow, from Oregon State University, and USDA (Sathuvalli and Mehlenbacher, 2012) are shown in green, and the Rutgers University collection is shown in red. The map demonstrates the additive nature of the new germplasm reported here.

used as inoculum were collected from infected trees growing in Rutgers University field plots. Disease pressure was also provided by natural spread from adjacent breeding nurseries and experimental plots harboring hundreds of infected plants. In addition, the susceptible seedlings within this planting added to the amount of inoculum as the study progressed.

\section{Evaluation of disease response}

Disease ratings followed the six-point rating index developed by Pinkerton et al. (1992): 0 = no visible EFB; $1=$ a single canker; $2=$ multiple cankers on a single branch; $3=$ a tree with several cankered branches; $4=$ greater than $50 \%$ of the tree's branches have cankers; and $5=$ all branches contain cankers, except for the basal sprouts. Disease ratings were collected in Jan. 2017 and again in 2018 following the plants' sixth, seventh, or eighth growing season. Previous studies have demonstrated that under field inoculations, five growing seasons provide sufficient time to observe plant phenotypes while minimizing escapes (Capik and Molnar, 2012; Leadbetter et al., 2016; Molnar et al., 2007, 2009).

To contextualize the EFB ratings, rating 0 is considered complete resistance, and ratings 1 and 2 are considered highly tolerant, as the canker growth does not typically cause abnormal tree growth or reduced nut production. Rating 3 is considered tolerant, with branch dieback and yield reduction over time. Ratings 4 and 5 are for susceptible individuals in which yield reduction occurs soon after cankering, and perennial spread of cankers leads to plant death in 5 to 7 years.

Disease response ratings were assigned to each seedling, and the means tabulated for each progeny (Table 1). The statistical significance of differences among progeny means were ascertained through a one-way analysis of variance using the AOV function in R 3.3.2 (R Core Team, 2014). A post hoc multiple mean comparison was then conducted using the Tukey-Kramer test and the HSD.test function. The disease class scores were presented in histograms indicating percentages of the total for each progeny to aid visualization and comparisons.

\section{Results and Discussion}

C. americana $\times$ C. aVellana F $_{1}$ Progenies. Useful resistance and tolerance was transmitted to seedlings in most of the 31 progenies. Across the entire study, $24 \%$ of the offspring were 
rated free of EFB, and $45 \%$ exhibited a degree of tolerance (i.e., ratings $1-3)$. The remaining offspring were susceptible with a rating of 4 or 5 , accounting for a respective $20 \%$ and $10 \%$ of the $\mathrm{F}_{1}$ bushes. However, the rate at which resistance and/or tolerance was transmitted varied widely by $C$. americana parent and across a full spectrum from high transmission to almost none (Fig. 2). Disease response ratings, progeny means (Table 2), and the percentages of seedlings for each disease rating per progeny are shown (Fig. 2). This wide variation in transmission of resistance indicates that the disease phenotype of the $C$. americana parent, most of which were evaluated in New Jersey under high disease pressure and found free of EFB (Capik and Molnar, 2012), is not a clear indicator of progeny performance. Progeny tests are necessary to evaluate a parent's breeding utility. Results also suggest that the $C$. avellana parent can play a role in the disease response of the progeny.

Twenty-seven progenies retained some level of resistance and/or tolerance, whereas four progenies were effectively lost to EFB (Table 2). Ratings of 0 and 3 were the most prevalent in these progenies, representing $26 \%$ and $33 \%$ of the seedlings, respectively, and a continuum of ratings from 0 to 5 was recorded in most progenies. On closer inspection, we noted three patterns for the disease rating distributions: continuous, bimodal, and no transmission (Fig. 3).

The first pattern is a continuous distribution, where a major intermediate peak was observed at a single rating within a more or less continuous distribution across the classes. The distribution reflected the "bell-shaped curve" typically observed for segregation of quantitative traits. Thirteen of the progenies exhibited a major peak at rating 3 or across ratings 3 and 4, suggesting that the respective $C$. americana parents carry quantitative (multigenic) resistance. The trait is partially recovered in the $F_{1}$ progeny in the form of tolerance (rating 3 ), which manifests itself as a high frequency of plants with intermediate phenotypes between the completely resistant $C$. americana and susceptible $C$. avellana parents. This pattern fits the previous descriptions of EFB on $C$. americana as an occasional occurrence of small cankers and general ability to abate perennial canker spread following infection (Capik and Molnar, 2012; Fuller, 1908; Weschcke, 1953). The disease class with the highest frequency varied in the progenies with continuous distributions. For eight progenies, the peak occurred exclusively at rating 3 , whereas the remaining five progenies of this distribution type held similarly high frequencies of progeny across ratings 3 and 4 . As mentioned previously, rating 4 is representative of a much higher degree of EFB (not suitable for reliable nut production) compared with rating 3 , and thus crossing this "ratings threshold" likely represents a loss of loci required for adequate quantitative resistance. Nevertheless, in clonal crops, individuals are selected, and even when rating 3 or 4 was most prevalent, the progenies still yielded some seedlings with ratings 0,1 , or 2 , which would be the target for further breeding or evaluation.

Interestingly, the choice of susceptible $C$. avellana parent appears to also influence the degree to which resistance is recovered, as previously observed by Molnar and Capik (2012b) and Muehlbauer et al. (2018). Here, the influence can be seen by comparing progenies OSU 09044 and Rutgers 11530 (Fig. 2 ), which both used the $C$. americana Pennsylvanian OSU 533.069 as the pistillate parent. The male parents of OSU 09044, which displayed a major peak across ratings 3 and 4 , come from a $C$. avellana pollen mix (Table 2). The male parent of Rutgers 11530, with a peak at rating 3 , is $C$. avellana Tonda di Giffoni, a cultivar shown to be somewhat tolerant to EFB in prior studies in Oregon (i.e., equivalent to rating 3) and New Jersey (i.e., equivalent to rating 4) (Capik and Molnar, 2012; Mehlenbacher et al., 2000, 2001, 2008; Pinkerton
Fig. 2. Bar plots of normalized eastern filbert blight (EFB) disease ratings are displayed by progeny, showing the proportion of offspring in each disease category. Disease ratings ranged from 0 (no disease) to 5 (much disease). Plants with ratings of 1 to 3 were considered tolerant of EFB, whereas ratings 4 and 5 were susceptible phenotypes. The figure shows that some level of resistance and tolerance is transmitted from most Corylus americana parents to their C. americana $\times$ Corylus avellana $\mathrm{F}_{1}$ hybrids families, but transmission occurs along a wide continuum. In addition, disease ratings of the entire population demonstrate the robust utility of $C$. americana as a source of resistance as well as the importance of parent selection. Although EFB-free and highly tolerant (ratings 1 and 2) progeny were common within the population, most seedlings displayed a rating of 3 or lower. 
Table 2. Eastern filbert blight (EFB) disease ratings in Corylus americana $\times$ Corylus avellana progenies exposed to Anisogramma anomala in New Jersey. Individual shrubs were rated on a scale of 0 (no disease) to 5 (disease on all branches). Differences among progeny means were compared using a one-way analysis of variance followed by a post hoc multiple mean comparison using the Tukey-Kramer test.

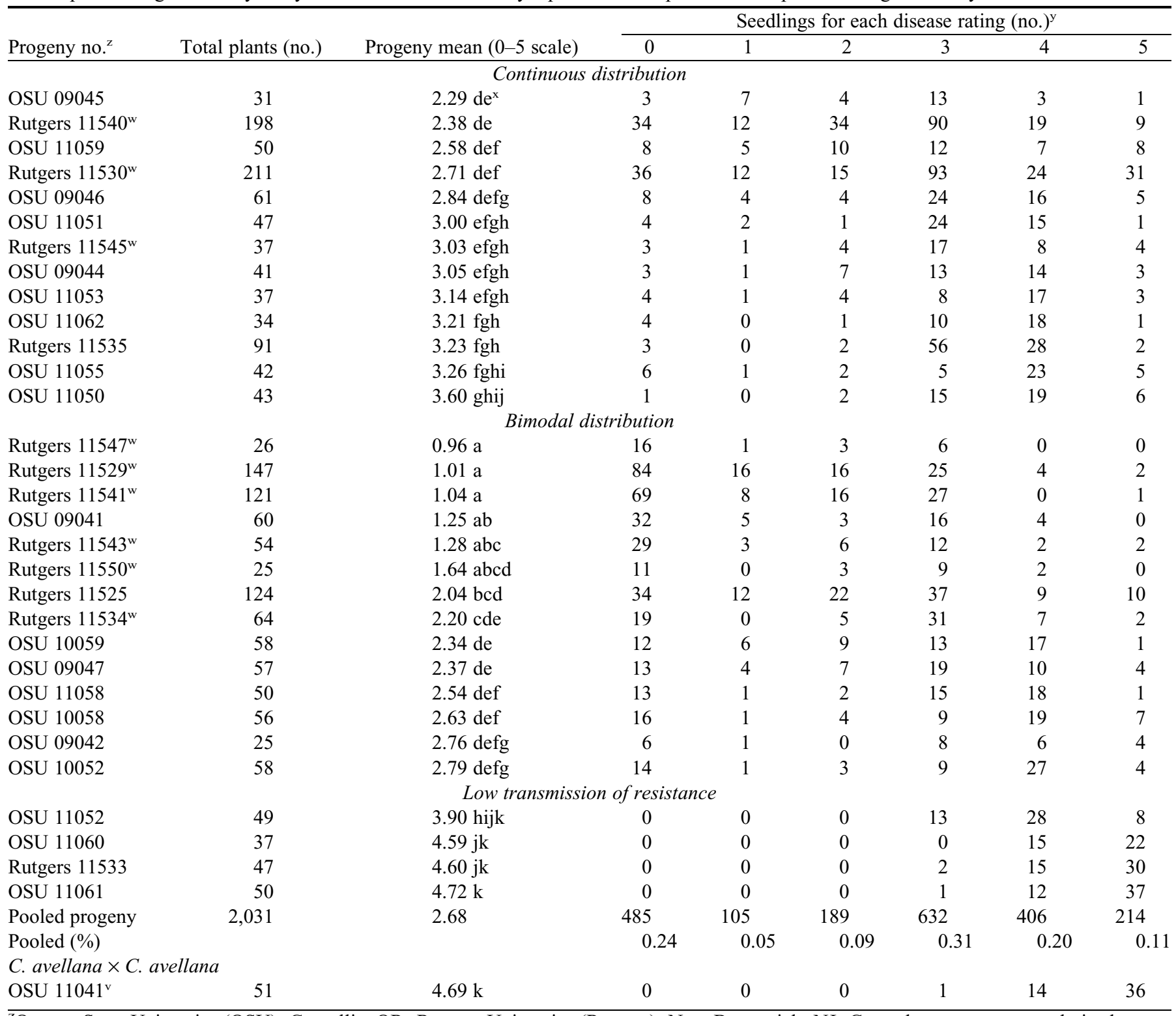

${ }^{\bar{z}}$ Oregon State University (OSU), Corvallis, OR; Rutgers University (Rutgers), New Brunswick, NJ; Control crosses were made in the year indicated by the first two digits of the progeny identification number. Continuous refers to a distribution in which a major peak at a single intermediate disease class was most prominent within a more or less continuous distribution among the other classes. Bimodal refers to a distribution that exhibited both a high frequency of EFB-free and tolerant individuals with major peaks occurring at ratings 0 and 3 .

${ }^{\mathrm{y}}$ Disease was rated in 2018 during the dormant season 6 to 8 years after field establishment and correspond to phenotypes as follows: $0=$ no visible EFB, 1 = a single canker, $2=$ multiple cankers on a single branch, $3=$ multiple branches with cankers, $4=$ more than $50 \%$ of branches have cankers, and $5=$ all branches have cankers or the plant has died from EFB.

${ }^{\mathrm{x}}$ The same letter following the progeny means indicates a lack of significant difference $(P<0.05)$.

${ }^{\text {w}}$ Progenies with 'Tonda di Giffoni' as the pollen parent.

${ }^{v}$ OSU 11041 is a control cross (OSU 1197.113 × OSU 1155.009) made in Oregon and expected to segregate for quantitative resistance from $C$. avellana based on its parentage.

et al., 1993). This comparison indicates that the $C$. avellana parent can contribute to the quantitative resistance and disease response of interspecific hybrids.

A bimodal distribution type was observed in 14 progenies, which exhibited both a high frequency of EFB-free (rating 0) and tolerant individuals with a major peak at rating 3 . Compiled histograms of these progenies are displayed (Fig. 4). Tolerance (ratings 1-3) was obtained at frequencies similar to the previously described progenies exhibiting continuous distributions (Table 2). However, the frequency of plants exhibiting resistance in these progenies was much higher and resulted in a defined peak at rating 0 , which is unlike what would be 


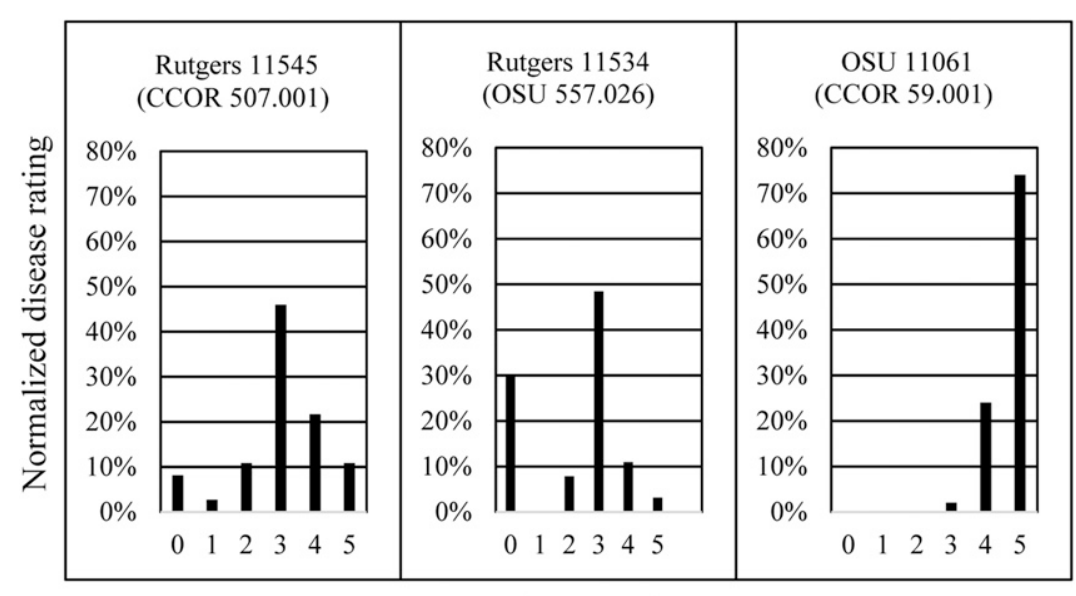

Disease rating

Fig. 3. Histograms illustrating the three distribution types observed in the Corylus americana $\times$ Corylus avellana $\mathrm{F}_{1}$ progenies, showing the proportion of offspring for each eastern filbert blight disease rating. Disease ratings ranged from 0 (no disease) to 5 (much disease). Plants with ratings of 1 to 3 were considered tolerant of eastern filbert blight, whereas ratings 4 and 5 were susceptible phenotypes. The continuous distribution of Rutgers 11545 (left) was observed in 13 progenies in which the largest peak occurred at either rating 3 or across ratings 3 and 4 . The bimodal distribution of Rutgers 11534 (center) was observed in 14 progenies, with peaks occurring at ratings 0 and 3 or ratings 0 and 3/4. Very little transmission, as in OSU 11061 (right), occurred in four progenies. Together, these histograms show that the genetic control of EFB resistance in C. americana varies, with sources segregating for minor loci, both major and minor loci, or not at all.

expected if disease response was under strict multigenic control. The frequency of resistant offspring was higher than expected. This distribution type is generally to be expected if a dominant allele (or two) was segregating in a background of quantitative resistance. $C$. americana and $A$. anomala share an extended coevolutionary history, in which long-term disease pressure often gives rise to a complex pathosystem with a variety of $R$ genes and corresponding pathogen effectors (PetitHoudenot and Fudal, 2017). In such systems, the cosegregation of two or more $R$ genes (e.g., two-gene epistatic model) is common, and both alleles must be recovered to obtain a rating of 0 . Two progenies with a similar bimodal distribution were previously observed by Molnar and Capik (2012b). However, although the regularity of this pattern of transmission had not yet been observed from a broad collection of $C$. americana, a single dominant gene for resistance has recently been mapped to LG 7 in $C$. americana 'Rush' (Bhattarai et al., 2017a). The frequent observation of this bimodal pattern suggests a promising outlook for the use of $C$. americana in systematic crossing by showing that amenable resistance is available within a geographically diverse collection of $C$. americana accessions.

These bimodal segregation patterns highlight parental genotypes that may be preferential for future breeding. The corresponding $C$. americana parents return a greater number of EFB-free and tolerant offspring and thus increase the opportunity to identify rare recombinant individuals during backcross generations. These accessions represent seedlings from nine different states, stretching the geographic range from North Dakota to New Jersey. Three accessions [OSU 532.076, OSU 557.125, and OSU 531.043 (Table 1)] appear the most promising as donor parents, as their disease rating means are significantly lower than most of the other bimodal progenies (Table 2).

In four progenies, plus the $C$. avellana $\times C$. avellana control progeny (OSU 11041), resistance and tolerance were recovered in few seedlings. The distribution of disease ratings for these prog- enies (Fig. 2) shows peaks at rating 4 or across ratings 4 and 5 (average progeny mean of 4.45). This segregation pattern suggests that quantitative resistance in these $C$. americana accessions is highly polygenic. Although this pattern characterizes only a small group of the tested progenies, it highlights the extent to which the recovery of the quantitative resistance of $C$. americana can vary and emphasizes the need for testcrosses before substantial investment in their use as breeding parents.

Across our study, nine progenies used the pollen parent 'Tonda di Giffoni' (Table 1), allowing separation of the $C$. americana female parents' contribution to the disease phenotypes of the half-sib progenies. For example, Rutgers 11545 exhibits a continuous distribution with a progeny mean of 3.03 , whereas Rutgers 11547 exhibits a bimodal pattern with a progeny mean of 0.96. Disease incidence in the remaining seven $C$. americana $\times$ 'Tonda di Giffoni' varies between C. americana parents, distinguishing the various contributions from the $C$. americana parents. Significantly lower progeny means were observed for some (but not all) of the C. americana $\times$ 'Tonda di Giffoni' crosses compared with other progenies in their respective distribution classes. The contribution of 'Tonda di Giffoni' to resistance and tolerance becomes clearer when comparing the progeny means of pooled disease ratings across all $C$. americana $\times$ 'Tonda di Giffoni' progenies to that of the other progenies. For continuous distributions, pooled progenies of 'Tonda di Giffoni' have a mean rating of 2.59 compared with a mean of 3.04 for the pooled ratings of all other progenies. The lower mean of 'Tonda di Giffoni' progenies is primarily due to a $12 \%$ increase in tolerant offspring (ratings $1-3$ ) and a $20 \%$ reduction in susceptible offspring. For the bimodal distributions, pooled means of 'Tonda di Giffoni' progenies were again lower (1.26) than those of other progenies (2.26). Quite interestingly, this difference is due to a $23 \%$ increase in EFB-free progeny in the 'Tonda di Giffoni' crosses and a corresponding decrease in the quantity of susceptible progeny; an equal amount of tolerant progeny (42\%) was obtained in both groups. Taken together, the 'Tonda di Giffoni' progenies are additional evidence that the C. avellana parent can contribute to the transmission of resistance and tolerance from $C$. americana to hybrid offspring, and furthermore, these bimodal progenies provide evidence for the hypothesis of interplay between qualitative and quantitative pathways contributed by both $C$. americana and $C$. avellana. This also indicates value in selecting $C$. avellana genotypes known to express a high level of tolerance, such as 'Sacajawea' (Mehlenbacher et al., 2008), for use in future interspecific hybrid crosses.

There are several underlying mechanisms of resistance that could allow for such high levels of complete resistance without clear goodness-of-fit to Mendelian segregation patterns. The combination of multiple quantitative trait loci can give an additive, strong quantitative defense response to confer 


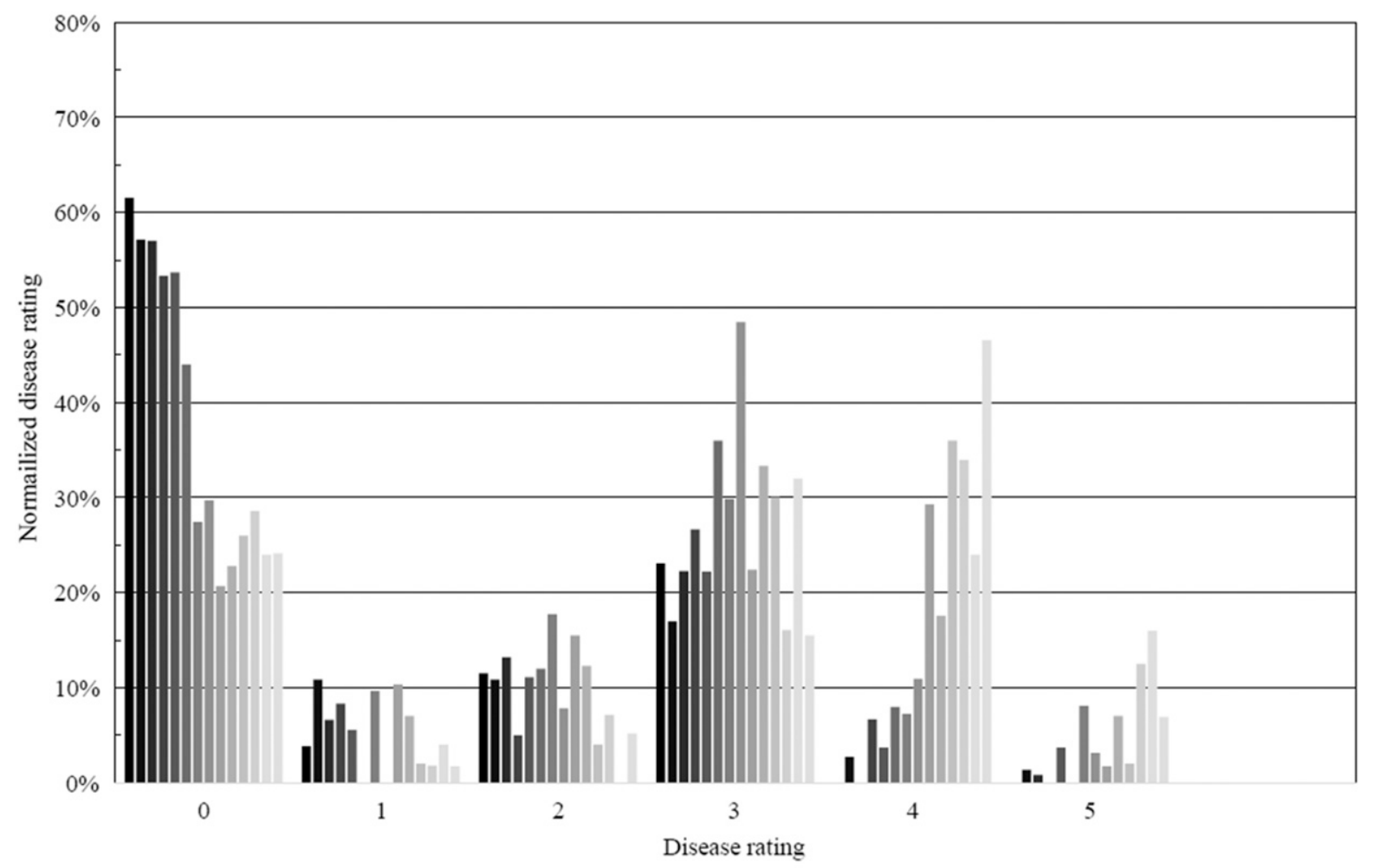

\begin{tabular}{|c|c|c|c|c|}
\hline -Rutgers 11547 & - Rutgers 11529 & - Rutgers 11541 & $=\mathrm{OSU} 09041$ & Rutgers 11543 \\
\hline - Rutgers 11550 & $=$ Rutgers 11525 & Rutgers 11534 & $=\mathrm{OSU} 10059$ & $=$ OSU 09047 \\
\hline OSU 11058 & $=$ OSU 10058 & OSU 09042 & OSU 10052 & \\
\hline
\end{tabular}

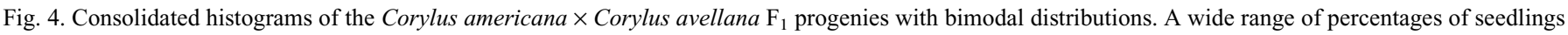
with complete resistance (rating 0) to eastern filbert blight was observed but without consensus for the segregation of monogenic resistance. Plants with ratings of 1 to 3 were considered tolerant of eastern filbert blight, whereas ratings 4 and 5 were susceptible phenotypes. These distributions represent families segregating for both major and minor resistance loci, which interestingly respond to the disease along a continuum and suggest genetic variation.

complete resistance (Niks et al., 2015), which was observed with Xanthomonas campestris in tomato [Solanum lycopersicum (Stall et al., 2009)]. In some cases, highly effective basal resistance can also yield complete resistance (Dangl and Jones, 2001; Niks et al., 2015). Pattern recognition receptor (e.g., receptor-like kinases) signaling of pathogen-associated molecular pattern triggered immunity with segregating downstream pathways is another possible explanation for this distribution pattern (Corwin and Kliebenstein, 2017; Poland et al., 2009). It is also possible that $R$ genes of the Anisogramma-Corylus pathosystem behave outside of the traditional gene-for-gene model that incites effector triggered immunity in which complete resistance is the consequence of a rapid hypersensitive response (i.e., localized cell death) following the recognition of a pathogen effector by a single $R$ gene (i.e., a pattern recognition receptor) (Coll et al., 2011; Jones and Dangl, 2006; Zhou et al., 2017).

The bimodal distributions may, or may not, reflect the presence of major $R$ genes. Segregation distortion for both phenotypic resistance and corresponding resistance-linked markers have been observed in many crosses between susceptible genotypes and those carrying a single dominant resistance locus (Bhattarai et al., 2017b, Mehlenbacher, 2018). The percentage of resistant offspring recovered in these progenies ranged from $20 \%$ to $75 \%$ (Bhattarai et al., 2017b; Colburn et al., 2015; Lunde et al., 2006; Sathuvalli et al., 2011b). Although the cause of distortion is not clear, it is hypothesized that reciprocal translocations are involved. Reciprocal translocations occur commonly in prevalent cultivars (Salesses and Bonnet, 1988; Torello Marinoni et al., 2018) and could lead to chromosomal rearrangements in gametic cells that distort segregation in either direction. Other researchers suggest this deviation is caused by "modifying" or transcription factors that must be coinherited with the major gene, and when absent, minor EFB infections (i.e., ratings 1 and 2) can occur despite the presence of an $R$ gene (Muehlbauer et al., 2018). Similar segregation distortion has been observed with apple scab [Venturia inaequalis (Crosby et al., 1990; Gessler and Pertot, 2012)] as well as other pathosystems involving biotrophic ascomycete pathogens like Zymoseptoria tritici (Chartrain et al., 2005; Saintenac et al., 2018), Leptosphaeria maculans (Parlange et al., 2009), and Verticillium dahliae (Castroverde et al., 2017; Hayes et al., 2011). Such distortions can complicate the interpretation of bimodal inheritance from new Corylus germplasms based on 
phenotyping and present an added challenge in readily identifying new $R$ genes, although DNA markers have been very useful to deconvolute segregation (Torello Marinoni et al., 2018). Nevertheless, the patterns provide a basis for interplay between qualitative and quantitative pathways and insight as to the possible models for resistance.

C. AMERICANA GERMPLASM COLLECTION. The collection of 1335 bushes representing 122 seed lots originates from 72 counties and 22 states (Supplemental Table 1), and its distribution is depicted by the geographic information systems map (Fig. 1). Previously collected germplasm preserved in the USDA-ARS-NCGR and university holdings, in addition to herbarium records of wild $C$. americana, are indicated to show the extent to which this new collection complements them. A subset of 616 bushes underwent long-term evaluation for EFB response, and disease ratings are reported by seed lot (Supplemental Table 2). At the final evaluation, 587 (95\%) of these trees remained free of disease symptoms (i.e., rating 0 ). The remaining 29 trees were represented by ratings 1 through 5 , where 20 individuals were tolerant (ratings 1-3) and the remaining 9 susceptible (ratings 4-5). Disease-free trees were present in all 62 seed lots. The evaluated plots of $C$. americana were directly adjacent to most of the hybrid seedlings discussed subsequently (those planted in 2012) and provide a stark contrast of disease infection under similar conditions. The multiple years of exposure reduce the likelihood that trees free of EFB simply escaped infection.

Given that the collection was derived from open-pollinated seeds from a broad geographic range, the results validate that $C$. americana populations carry a high level of innate resistance to EFB. These results also corroborate prior evaluation of clonal $C$. americana in New Jersey, where 51 accessions from the OSU and USDA-ARS-NCGR collections were exposed to EFB and 49 remained free of disease at the conclusion of the study (Capik and Molnar, 2012). Some of the 49 clones that remained free of EFB were used to develop the interspecific hybrid progenies evaluated in this current study. Further, the collection reported here is a robust expansion of available $C$. americana germplasm (Fig. 1). Corylus americana is a highly heterozygous, obligate outcrossing species that is wind-pollinated and sporophytically self-incompatible (Demchik et al., 2018; Sathuvalli and Mehlenbacher, 2012). As a result, seeds of a wild plant are typically derived from a multitude of pollen parents. The reproductive biology of $C$. americana, coupled with the wide geographic range represented in this collection and the high genetic variation in the pathogen (Muehlbauer et al., 2018), indicate that this collection holds plants representing diverse sources of genetic resistance to EFB.

\section{Conclusions}

Our study confirms $C$. americana as an abundant source of EFB resistance and tolerance, which is recoverable in interspecific $\mathrm{F}_{1}$ offspring from a wide diversity of parents. Although EFB-free individuals were common in the studied germplasm collection, as well as the parents used to make the crosses, the transmission of resistance to interspecific progeny was variable and at times absent. Thus, transmission from specific $C$. americana parents was not predictable based on its phenotype, and some form of test crossing is required to identify the most promising genotypes for use in breeding. Due to the long maturity times of hazelnut where test crosses are not always feasible, a practical approach may be to make many crosses using a diversity of parents, select the best offspring, and move forward expecting that a portion of the offspring or entire progenies (in some cases) will not be useful. However, now that the recovery of resistance from $C$. americana has been demonstrated using a diversity of parents, resources can be dedicated to developing a greater number of large progenies with more confidence. This study represents a significant step toward better informed utilization of $C$. americana in hybrid hazelnut breeding and points to a need for additional research to elucidate the genetic control and mechanisms of resistance. The results of the $F_{1}$ progenies demonstrate that a wider collection of wild $C$. americana accessions should be tested as donor parents, which can now be pursued further using the collection reported here. In addition, a greater diversity of $C$. avellana parents with known phenotypes should be systematically incorporated into such studies to better ascertain the species' effect on inheritance.

\section{Literature Cited}

Bassil, N., P. Boccacci, R. Botta, J. Postman, and S. Mehlenbacher. 2013. Nuclear and chloroplast microsatellite markers to assess genetic diversity and evolution in hazelnut species, hybrids and cultivars. Genet. Resources Crop Evol. 60:543-568.

Bhattarai, G., S.A. Mehlenbacher, and D.C. Smith. 2017a. Eastern filbert blight disease resistance from Corylus americana 'Rush' and selection 'Yoder \#5' maps to linkage group 7. Tree Genet. Genomes $13: 45$.

Bhattarai, G., S.A. Mehlenbacher, and D.C. Smith. 2017b. Inheritance and linkage mapping of eastern filbert blight disease resistance in 'Uebov' hazelnut. J. Amer. Soc. Hort. Sci. 142:289-297.

Braun, L.C., M.C. Demchik, J.A. Fischbach, K. Turnquist, and A. Kerns. 2018. Yield, quality and genetic diversity of hybrid hazelnut selections in the upper midwest of the USA. Agrofor. Syst. 93:10811091.

Capik, J.M. and T.J. Molnar. 2012. Assessment of host (Corylus sp.) resistance to eastern filbert blight in New Jersey. J. Amer. Soc. Hort. Sci. 137:157-172.

Capik, J.M., M. Muehlbauer, A. Novy, J.A. Honig, and T.J. Molnar. 2013. Eastern filbert blight-resistant hazelnuts from Russia, Ukraine, and Poland. HortScience 48:466-473.

Castroverde, C.D.M., X. Xu, J. Blaya Fernández, R.N. Nazar, and J. Robbs. 2017. Epistatic influence in tomato Vel-mediated resistance. Plant Biol. 19:843-847.

Chartrain, L., P.A. Brading, and J.K.M. Brown. 2005. Presence of the Stb6 gene for resistance to septoria tritici blotch (Mycosphaerella graminicola) in cultivars used in wheat-breeding programmes worldwide. Plant Pathol. 54:134-143.

Chen, H., S.A. Mehlenbacher, and D.C. Smith. 2007. Hazelnut accessions provide new sources of resistance to eastern filbert blight. HortScience 42:466-469.

Chen, H.L., S.A. Mehlenbacher, and D.C. Smith. 2005. AFLP markers linked to eastern filbert blight resistance from OSU 408.040 hazelnut. J. Amer. Soc. Hort. Sci. 130:412-417.

Colburn, B.C., S.A. Mehlenbacher, V.R. Sathuvalli, and D.C. Smith. 2015. Eastern filbert blight resistance in hazelnut accessions 'Culplà', 'Crvenje', and OSU 495.072. J. Amer. Soc. Hort. Sci. 140:191-200.

Coll, N., P. Epple, and J. Dangl. 2011. Programmed cell death in the plant immune system. Cell Death Differ. 18:1247-1256.

Corwin, J.A. and D.J. Kliebenstein. 2017. Quantitative resistance: More than just perception of a pathogen. Plant Cell 29:655-665.

Coyne, C.J., S.A. Mehlenbacher, and D.C. Smith. 1998. Sources of resistance to eastern filbert blight in hazelnut. J. Amer. Soc. Hort. Sci. 123:253-257. 
Crosby, J., J. Janick, P. Pecknold, S. Korban, P. O'Connor, S. Ries, J. Goffreda, and A. Voordeckerss. 1990. Breeding apples for scab resistance: 1945-1990. Acta Hort. 317:43-70.

Dangl, J.L. and J.D.G. Jones. 2001. Plant pathogens and integrated defence responses to infection. Nature 411:826-833.

Demchik, M., A. Kern, L. Braun, J. Fischbach, and K. Turnquist. 2018. Genetic diversity of American hazelnut in the upper midwest, USA. Agrofor. Syst. 92:1507-1516.

Demchik, M., U.-S. Point, and D. Wyse. 2011. Hazelnut production potential in the upper midwest: A report on hybrid hazelnut yields. Univ. Wisconsin Ext. Res. Bul. 17.

Drumke, J.S. 1964. A systematic survey of Corylus in North America. Univ. Tennessee, Knoxville, PhD Diss.

Erdogan, V. and S.A. Mehlenbacher. 2000a. Phylogenetic relationships of Corylus species (Betulaceae) based on nuclear ribosomal DNA ITS region and chloroplast matK gene sequences. Syst. Bot. 25:727-737.

Erdogan, V. and S.A. Mehlenbacher. 2000b. Interspecific hybridization in hazelnut (Corylus). J. Amer. Soc. Hort. Sci. 125:489497.

Fischbach, J. 2017. A production and economic model for hedgerow hazelnut production in the midwestern United States. 1 Feb. 2019. $<$ www.midwesthazelnuts.org $>$.

Food and Agriculture Organization of the United Nations. 2017. FAOSTAT. Agricultual production, crops. 30 May 2019. <http:// www.fao.org/faostat/en/\#data/QC/visualize>.

Fuller, A.S. 1908. The nut culturist. Orange Judd, New York, NY. Gessler, C. and I. Pertot. 2012. Vf scab resistance of Malus. Trees 26:114.

Gleason, H.A. and A. Cronquist. 1963. Manual of vascular plants of northeastern United States and adjacent Canada. Van Nostrand, New York, NY.

Hammond, E. 2006. Identifying superior hybrid hazelnut plants in southeast Nebraska. Univ. Nebraska, Lincoln, M.S. Thesis.

Hayes, R.J., L.K. McHale, G.E. Vallad, M.J. Truco, R.W. Michelmore, S.J. Klosterman, K. Maruthachalam, and K.V. Subbarao. 2011. The inheritance of resistance to Verticillium wilt caused by race 1 isolates of Verticillium dahliae in the lettuce cultivar La Brillante. Theor. Appl. Genet. 123:509-517.

Johnson, K. and J. Pinkerton. 2002. Eastern filbert blight, p. 44-46. In: J.W. Pscheidt (ed.). Compendium of nut crop diseases in temperate zones. APS Press, St. Paul, MN.

Jones, J.D.G. and J.L. Dangl. 2006. The plant immune system. Nature 444:323-329.

Leadbetter, C.W., J.M. Capik, S.A. Mehlenbacher, and T.J. Molnar. 2016. Hazelnut accessions from Russia and Crimea transmit resistance to eastern filbert blight. J. Amer. Pomol. Soc. 70:92109.

Lunde, C.F., S.A. Mehlenbacher, and D.C. Smith. 2000. Survey of hazelnut cultivars for response to eastern filbert blight inoculation. HortScience 35:729-731.

Lunde, C.F., S.A. Mehlenbacher, and D.C. Smith. 2006. Segregation for resistance to eastern filbert blight in progeny of 'Zimmerman' hazelnut. J. Amer. Soc. Hort. Sci. 131:731-737.

Mehlenbacher, S.A. 1994. Genetic improvement of the hazelnut. Acta Hort. 351:23-38.

Mehlenbacher, S.A. 2018. Breeding hazelnuts resistant to eastern filbert blight. Acta Hort. 1226:73-78.

Mehlenbacher, S.A. 1991. Hazelnuts (Corylus). Genetic resources in temperate fruit and nut crops. Acta Hort. 290:789-836.

Mehlenbacher, S.A., A.N. Azarenko, D.C. Smith, and R. McCluskey. 2000. 'Lewis' hazelnut. HortScience 35:314-315.

Mehlenbacher, S.A., A.N. Azarenko, D.C. Smith, and R. McCluskey. 2001. 'Clark' hazelnut. HortScience 36:995-996.

Mehlenbacher, S.A., A.N. Azarenko, D.C. Smith, and R. McCluskey. 2007. 'Santiam' hazelnut. HortScience 42:715-717.

Mehlenbacher, S.A., D.C. Smith, and R.L. McCluskey. 2008. 'Sacajawea' hazelnut. HortScience 43:255-257.
Mehlenbacher, S.A., D.C. Smith, and R.L. McCluskey. 2009. 'Yamhill' hazelnut. HortScience 44:845-847.

Mehlenbacher, S.A., D.C. Smith, and R.L. McCluskey. 2011. 'Jefferson' hazelnut. HortScience 46:662-664.

Mehlenbacher, S.A., D.C. Smith, and R.L. McCluskey. 2013. 'Dorris' hazelnut. HortScience 48:796-799.

Mehlenbacher, S.A., D.C. Smith, and R.L. McCluskey. 2014. 'Wepster' hazelnut. HortScience 49:346-349.

Mehlenbacher, S.A., D.C. Smith, and R.L. McCluskey. 2016. 'McDonald' hazelnut. HortScience 51:757-760.

Mehlenbacher, S.A., M.M. Thompson, and H.R. Cameron. 1991. Occurrence and inheritance of resistance to eastern filbert blight in Gasaway hazelnut. HortScience 26:410-411.

Molnar, T.J., J.C. Goffreda, and C.R. Funk. 2005. Developing hazelnuts for the eastern United States. Acta Hort. 686:609-618.

Molnar, T.J., J. Lombardoni, M. Muehlbauer, J. Honig, S.A. Mehlenbacher, and J. Capik. 2018. Progress breeding for resistance to eastern filbert blight in the eastern United States. Acta Hort. 1226:79-86.

Molnar, T.J. 2011. Corylus, p. 15-48. In: C. Kole (ed.). Wild crop relatives: Genomic and breeding resources. Springer, Berlin/Heidelberg, Germany.

Molnar, T.J. and J. Capik. 2012a. Advances in hazelnut research in North America. Acta Hort. 940:57-65.

Molnar, T.J. and J.M. Capik. 2012b. Eastern filbert blight susceptibility of american $\times$ european hazelnut progenies. HortScience 47:1412-1418.

Molnar, T.J., J.M. Capik, and J.C. Goffreda. 2009. Response of hazelnut progenies from known resistant parents to Anisogramma anomala in New Jersey, USA. Acta Hort. 845:73-82.

Molnar, T.J., D.E. Zaurov, J.C. Goffreda, and S.A. Mehlenbacher. 2007. Survey of hazelnut germplasm from Russia and Crimea for response to eastern filbert blight. HortScience 42:51-56.

Muehlbauer, M., J.M. Capik, T.J. Molnar, and S.A. Mehlenbacher. 2018. Assessment of the 'Gasaway' source of resistance to eastern filbert blight in New Jersey. Scientia Hort. 235:367-372.

Muehlbauer, M.F., J.A. Honig, J.M. Capik, J.N. Vaiciunas, and T.J. Molnar. 2014. Characterization of eastern filbert blight-resistant hazelnut germplasm using microsatellite markers. J. Amer. Soc. Hort. Sci. 139:399-432.

Niks, R.E., X. Qi, and T.C. Marcel. 2015. Quantitative resistance to biotrophic filamentous plant pathogens: Concepts, misconceptions, and mechanisms. Annu. Rev. Phytopathol. 53:445-470.

Parlange, F., G. Daverdin, I. Fudal, M.L. Kuhn, M.H. Balesdent, F. Blaise, B. Grezes-Besset, and T. Rouxel. 2009. Leptosphaeria maculans avirulence gene AvrLm4-7 confers a dual recognition specificity by the $R \operatorname{lm} 4$ and $R \operatorname{lm} 7$ resistance genes of oilseed rape, and circumvents $R \operatorname{lm} 4$-mediated recognition through a single amino acid change. Mol. Microbiol. 71:851-863.

Petit-Houdenot, Y. and I. Fudal. 2017. Complex interactions between fungal avirulence genes and their corresponding plant resistance genes and consequences for disease resistance management. Front. Plant Sci. 8:1072.

Pinkerton, J.N., K.B. Johnson, S.A. Mehlenbacher, and J.W. Pscheidt. 1993. Susceptibility of european hazelnut clones to eastern filbert blight. Plant Dis. 77:261-266.

Pinkerton, J.N., K.B. Johnson, K.M. Theiling, and J.A. Griesbach. 1992. Distribution and characteristics of the eastern filbert blight epidemic in western Oregon. Plant Dis. 76:1179-1182.

Poland, J.A., P.J. Balint-Kurti, R.J. Wisser, R.C. Pratt, and R.J. Nelson. 2009. Shades of gray: The world of quantitative disease resistance. Trends Plant Sci. 14:21-29.

$\mathrm{R}$ Core Team 2014. The $\mathrm{R}$ project for statistical computing. $\mathrm{R}$ Foundation for Statistical Computing, Vienna, Austria.

Rutter, M. 1991. Variation in resistance to eastern filbert blight in hybrid hazelnuts. Ann. Rpt. Northern Nut Growers Assn. 82:159162.

Rutter, P. 1987. Badgersett research farm - Plantings, projects, and goals. Annu. Rpt. Northern Nut Growers Assn. 78:173-186. 
Saintenac, C., W.-S. Lee, F. Cambon, J.J. Rudd, R.C. King, W. Marande, S.J. Powers, H. Bergès, A.L. Phillips, C. Uauy, K.E. Hammond-Kosack, T. Langin, and K. Kanyuka. 2018. Wheat receptor-kinase-like protein Stb6 controls gene-for-gene resistance to fungal pathogen Zymoseptoria tritici. Nat. Genet. 50:368-374.

Salesses, G. and A. Bonnet. 1988. Étude cytogénétique d'hybrides entre variétés de noisetier (Corylus avellana) porteuses d'une translocation à l'état hétérozygote. Cytologia (Tokyo) 53:407413.

Sathuvalli, V.R., H. Chen, S.A. Mehlenbacher, and D.C. Smith. 2011a. DNA markers linked to eastern filbert blight resistance in 'Ratoli' hazelnut (Corylus avellana L.). Tree Genet. Genomes 7:337-345.

Sathuvalli, V.R. and S.A. Mehlenbacher. 2012. Characterization of american hazelnut (Corylus americana) accessions and Corylus americana $\times$ Corylus avellana hybrids using microsatellite markers. Genet. Resources Crop Evol. 59:1055-1075.

Sathuvalli, V.R., S.A. Mehlenbacher, B.C. Peterschmidt, and D.C. Smith. 2014. Current status of eastern filbert blight resistance sources and mapping. Acta Hort. 1052:27-34.

Sathuvalli, V.R., S.A. Mehlenbacher, and D.C. Smith. 2011b. DNA markers linked to eastern filbert blight resistance from a hazelnut selection from the Republic of Georgia. J. Amer. Soc. Hort. Sci. $136: 350-357$.
Slate, G.L. 1969. Filberts - Including varieties grown in the east, p. 287-293. In: R.A. Jaynes (ed.). Handbook of North American nut trees. Northern Nut Growers Assn., Knoxville, TN.

Stall, R.E., J.B. Jones, and G.V. Minsavage. 2009. Durability of resistance in tomato and pepper to xanthomonads causing bacterial spot. Annu. Rev. Phytopathol. 47:265-284.

Technavioa. 2017. Global hazelnut market 2017-2021. 1 Feb. 2019. $<$ https://www.technavio.com/report/global-hazelnut-market-20172021>.

Torello Marinoni, D., N. Valentini, E. Portis, A. Acquadro, C. Beltramo, S.A. Mehlenbacher, T.C. Mockler, E.R. Rowley, and R. Botta. 2018. High density SNP mapping and QTL analysis for time of leaf budburst in Corylus avellana L. PLoS One 13:e 0195408.

Thompson, M.M., H.B. Lagerstedt, and S.A. Mehlenbacher. 1996. Hazelnuts, p. 125-184. In: J. Janick and J.N. Moore (eds.). Fruit breeding. Vol. 3. Nuts. Wiley, New York, NY.

U.S. Department of Agriculture. 2018. Noncitrus fruits and nuts 2017 summary. 1 Feb. 2019. <https://www.nass.usda.gov/Publications/ Todays_Reports/reports/ncit0618.pdf>.

Weschcke, C. 1953. Growing nuts in the north. Webb, St. Paul, MN.

Weschcke, C. 1963. Forty-three years of active work in nutgrowing. Annu. Rpt. Northern Nut Growers Assn. 54:63-65.

Zhou, J.-M., D. Tang, and G. Wang. 2017. Receptor kinases in plant pathogen interactions: More than pattern recognition. Plant Cell 29:618-637. 
Supplemental Table 1. Corylus americana germplasm at the Rutgers University Research and Extension Center in Cream Ridge, NJ, by state and county of origin.

\begin{tabular}{|c|c|c|c|}
\hline U.S. state & County & Total plants (no.) & Seed lot no. ${ }^{\mathrm{z}}$ \\
\hline \multirow[t]{2}{*}{ Arkansas } & & 1 & \\
\hline & Saline & 1 & 12556 \\
\hline \multirow[t]{4}{*}{ Iowa } & & 45 & \\
\hline & Clarke & 21 & 11607 \\
\hline & Jones & 23 & 12508 \\
\hline & Union & 1 & 11594 \\
\hline \multirow[t]{5}{*}{ Illinois } & & 34 & \\
\hline & Cook & 11 & 12533 \\
\hline & Menard & 20 & 11567 \\
\hline & Pike & 1 & 10543 \\
\hline & Rock Island & 2 & 11612 \\
\hline \multirow[t]{3}{*}{ Indiana } & & 40 & \\
\hline & Steuben & 32 & 14553,15563 \\
\hline & Tippecanoe & 8 & 12560 \\
\hline \multirow[t]{2}{*}{ Kentucky } & & 30 & \\
\hline & Casey & 30 & 11568 \\
\hline \multirow[t]{2}{*}{ Massachusetts } & & 22 & \\
\hline & Nantucket & 22 & $10532,11605,11606$ \\
\hline \multirow[t]{2}{*}{ Maine } & & 2 & \\
\hline & Lincoln & 2 & 10520 \\
\hline \multirow[t]{8}{*}{ Michigan } & & 116 & \\
\hline & Calhoun & 7 & 11602 \\
\hline & Ingham & 4 & $14542,14543,16518-16522$ \\
\hline & Jackson & 43 & $14537,14539,14540$ \\
\hline & Kalamazoo & 7 & 14538 \\
\hline & Montmorency & 16 & 14544 \\
\hline & Ontonagon & 16 & $11588,12540,16518-16522$ \\
\hline & Washtenaw & 23 & 11587 \\
\hline \multirow[t]{10}{*}{ Minnesota } & & 199 & \\
\hline & Aiken & 49 & 11563,11571 \\
\hline & Anoka & 2 & 12553 \\
\hline & Chisago & 34 & 11579 \\
\hline & Crow Wing & 3 & 11608 \\
\hline & Fillmore & 9 & 11599 \\
\hline & Isanti & 64 & $14551,15568,15569$ \\
\hline & Mississippi River & 29 & 11565,15566 \\
\hline & Sherbune & 7 & 11601 \\
\hline & Washington & 2 & 12509 \\
\hline \multirow[t]{3}{*}{ Missouri } & & 33 & \\
\hline & Jackson & 29 & 11613 \\
\hline & Macon & 4 & 11583 \\
\hline \multirow[t]{2}{*}{ North Carolina } & & 10 & \\
\hline & Madison & 10 & 12561 \\
\hline \multirow[t]{3}{*}{ North Dakota } & & 56 & \\
\hline & Burleigh & 40 & 12547,15564 \\
\hline & Barnes & 16 & 15567 \\
\hline \multirow[t]{3}{*}{ Nebraska } & & 119 & \\
\hline & Lancaster & 1 & 11600 \\
\hline & Richardson & 118 & $10556-10579,12507$ \\
\hline \multirow[t]{4}{*}{ New Jersey } & & 43 & \\
\hline & Mercer & 27 & 11570 \\
\hline & Middlesex & 6 & 11554 \\
\hline & Morris & 10 & $11578 \mathrm{~A}$ \\
\hline \multirow[t]{4}{*}{ Ohio } & & 207 & \\
\hline & Belmont & 23 & 11569 \\
\hline & Butler & 48 & $15571-15577$ \\
\hline & Carroll & 128 & $15572-15576$ \\
\hline
\end{tabular}


Supplemental Table 1. Continued.

\begin{tabular}{|c|c|c|c|}
\hline U.S. state & County & Total plants (no.) & Seed lot no. ${ }^{z}$ \\
\hline & Richland & 5 & 11610 \\
\hline & Warren & 0 & $13552-13555$ \\
\hline & Wayne & 3 & 12552 \\
\hline \multirow[t]{7}{*}{ Pennsylvania } & Adams & 1 & 13564,13565 \\
\hline & Beaver & 19 & 14555,15570 \\
\hline & Crawford & 21 & 11575 \\
\hline & Franklin & 25 & 10537 \\
\hline & Lancaster & 4 & 12550 \\
\hline & Lycoming & 31 & 11574 \\
\hline & Westmore & 5 & 12557 \\
\hline South Dakota & & 2 & \\
\hline \multirow[t]{3}{*}{ Virginia } & & 8 & \\
\hline & Gloucester & 3 & 12548 \\
\hline & Nelson & 5 & 13561 \\
\hline \multirow[t]{9}{*}{ Wisconsin } & & 166 & \\
\hline & Adams & 23 & 10542 \\
\hline & Burnett & 14 & 10530 \\
\hline & Dane & 20 & 11591 \\
\hline & Jefferson & 3 & 12543 \\
\hline & Langlade & 8 & 12538 \\
\hline & Marathon & 1 & 12546 \\
\hline & Marinette & 27 & $12510,12539,12541,12551$ \\
\hline & Oneida & 13 & $11585,12535,12536$ \\
\hline
\end{tabular}

${ }^{\bar{z}}$ Seed lots received from cooperators were assigned numbers by the Rutgers University breeding program. 
Supplemental Table 2. Disease ratings for the subset of the Corylus americana germplasm collection rated in Winter 2018 after seven seasons of growth under high disease pressure from Anisogramma anomala.

\begin{tabular}{|c|c|c|c|c|c|c|c|c|c|c|}
\hline \multirow[b]{2}{*}{ Seed lot no. ${ }^{z}$} & \multirow[b]{2}{*}{ County } & \multirow[b]{2}{*}{ U.S. state ${ }^{\mathrm{x}}$} & \multirow[b]{2}{*}{ Total plants (no.) ${ }^{\mathrm{w}}$} & \multicolumn{7}{|c|}{ Seedlings for each disease rating (no.) ${ }^{\mathrm{w}, \mathrm{v}}$} \\
\hline & & & & Avg & 0 & 1 & 2 & 3 & 4 & 5 \\
\hline 10520 & Jefferson & ME & 2 & 0 & 2 & 0 & 0 & 0 & 0 & 0 \\
\hline 10530 & Grantsburg & WI & 15 & 0 & 15 & 0 & 0 & 0 & 0 & 0 \\
\hline 10532 & Nantucket & $\mathrm{CT}$ & 16 & 0 & 16 & 0 & 0 & 0 & 0 & 0 \\
\hline 10537 & Willow Hill & PA & 25 & 1.60 & 14 & 0 & 0 & 5 & 5 & 1 \\
\hline 10542 & Adams & WI & 23 & 0 & 23 & 0 & 0 & 0 & 0 & 0 \\
\hline 10543 & Pike & IL & 1 & 0 & 1 & 0 & 0 & 0 & 0 & 0 \\
\hline 10556 & Richardson & NE & 5 & 0 & 5 & 0 & 0 & 0 & 0 & 0 \\
\hline 10557 & Richardson & NE & 5 & 0 & 5 & 0 & 0 & 0 & 0 & 0 \\
\hline 10559 & Richardson & $\mathrm{NE}$ & 4 & 0 & 4 & 0 & 0 & 0 & 0 & 0 \\
\hline 10560 & Richardson & NE & 5 & 0 & 5 & 0 & 0 & 0 & 0 & 0 \\
\hline 10561 & Richardson & NE & 4 & 0 & 4 & 0 & 0 & 0 & 0 & 0 \\
\hline 10562 & Richardson & $\mathrm{NE}$ & 3 & 0 & 3 & 0 & 0 & 0 & 0 & 0 \\
\hline 10563 & Richardson & NE & 5 & 0 & 5 & 0 & 0 & 0 & 0 & 0 \\
\hline 10564 & Richardson & NE & 3 & 0 & 3 & 0 & 0 & 0 & 0 & 0 \\
\hline 10565 & Richardson & NE & 4 & 0 & 4 & 0 & 0 & 0 & 0 & 0 \\
\hline 10566 & Richardson & NE & 4 & 0 & 4 & 0 & 0 & 0 & 0 & 0 \\
\hline 10567 & Richardson & NE & 2 & 0 & 2 & 0 & 0 & 0 & 0 & 0 \\
\hline 10568 & Richardson & NE & 3 & 0 & 3 & 0 & 0 & 0 & 0 & 0 \\
\hline 10569 & Richardson & NE & 4 & 0 & 4 & 0 & 0 & 0 & 0 & 0 \\
\hline 10570 & Richardson & $\mathrm{NE}$ & 3 & 0 & 3 & 0 & 0 & 0 & 0 & 0 \\
\hline 10571 & Richardson & $\mathrm{NE}$ & 5 & 0 & 5 & 0 & 0 & 0 & 0 & 0 \\
\hline 10572 & Richardson & NE & 5 & 0 & 5 & 0 & 0 & 0 & 0 & 0 \\
\hline 10573 & Richardson & $\mathrm{NE}$ & 4 & 0 & 4 & 0 & 0 & 0 & 0 & 0 \\
\hline 10574 & Richardson & NE & 5 & 0 & 5 & 0 & 0 & 0 & 0 & 0 \\
\hline 10575 & Richardson & NE & 1 & 0 & 1 & 0 & 0 & 0 & 0 & 0 \\
\hline 10576 & Richardson & NE & 3 & 0 & 3 & 0 & 0 & 0 & 0 & 0 \\
\hline 10577 & Richardson & NE & 2 & 0 & 2 & 0 & 0 & 0 & 0 & 0 \\
\hline 10578 & Richardson & NE & 4 & 1.00 & 3 & 0 & 0 & 0 & 1 & 0 \\
\hline 10579 & Richardson & $\mathrm{NE}$ & 4 & 0 & 4 & 0 & 0 & 0 & 0 & 0 \\
\hline 10581 & Center & PA & 9 & 0 & 9 & 0 & 0 & 0 & 0 & 0 \\
\hline 11554 & Cream Ridge & NJ & 6 & 1.83 & 2 & 1 & 1 & 0 & 2 & 0 \\
\hline 11563 & Aiken & $\mathrm{MN}$ & 22 & 0 & 22 & 0 & 0 & 0 & 0 & 0 \\
\hline 11564 & Butler & PA & 3 & 0 & 3 & 0 & 0 & 0 & 0 & 0 \\
\hline 11565 & Mississippi River & $\mathrm{MN}$ & 21 & 0 & 21 & 0 & 0 & 0 & 0 & 0 \\
\hline 11567 & Menard & IL & 25 & 0.04 & 23 & 0 & 1 & 1 & 0 & 0 \\
\hline 11568 & Casey & KY & 23 & 0.04 & 22 & 1 & 0 & 0 & 0 & 0 \\
\hline 11569 & Belmont & $\mathrm{OH}$ & 24 & 0 & 24 & 0 & 0 & 0 & 0 & 0 \\
\hline 11570 & Mercer & NJ & 24 & 0.04 & 23 & 1 & 0 & 0 & 0 & 0 \\
\hline 11571 & Aiken & $\mathrm{MN}$ & 22 & 0 & 22 & 0 & 0 & 0 & 0 & 0 \\
\hline 11574 & Hughesville & PA & 20 & 0 & 20 & 0 & 0 & 0 & 0 & 0 \\
\hline 11575 & Titusville & PA & 15 & 0.13 & 14 & 0 & 1 & 0 & 0 & 0 \\
\hline 11577 & Prentice & WI & 24 & 0 & 24 & 0 & 0 & 0 & 0 & 0 \\
\hline $11578 \mathrm{~A}$ & Morris & NJ & 10 & 0.30 & 9 & 0 & 0 & 1 & 0 & 0 \\
\hline 11579 & Stacy & $\mathrm{MN}$ & 24 & 0 & 24 & 0 & 0 & 0 & 0 & 0 \\
\hline 11583 & Ethel & MO & 7 & 0 & 7 & 0 & 0 & 0 & 0 & 0 \\
\hline 11585 & Oneida & WI & 1 & 0 & 1 & 0 & 0 & 0 & 0 & 0 \\
\hline 11587 & Pittsfield & MI & 14 & 0.08 & 13 & 1 & 0 & 0 & 0 & 0 \\
\hline 11591 & Madison & WI & 23 & 0 & 23 & 0 & 0 & 0 & 0 & 0 \\
\hline 11593 & West Subury & PA & 8 & 0 & 8 & 0 & 0 & 0 & 0 & 0 \\
\hline 11594 & Union & IA & 1 & 1 & 0 & 1 & 0 & 0 & 0 & 0 \\
\hline 11601 & Livonia & $\mathrm{MN}$ & 10 & 0 & 10 & 0 & 0 & 0 & 0 & 0 \\
\hline 11602 & Calhoun & MI & 7 & 0 & 7 & 0 & 0 & 0 & 0 & 0 \\
\hline 11603 & Arpin & WI & 24 & 0.04 & 23 & 1 & 0 & 0 & 0 & 0 \\
\hline 11604 & Venturini & VA & 7 & 0 & 7 & 0 & 0 & 0 & 0 & 0 \\
\hline 11605 & Nantucket & $\mathrm{CT}$ & 3 & 0 & 3 & 0 & 0 & 0 & 0 & 0 \\
\hline 11606 & Nantucket & $\mathrm{CT}$ & 9 & 0 & 9 & 0 & 0 & 0 & 0 & 0 \\
\hline
\end{tabular}


Supplemental Table 2. Continued.

\begin{tabular}{|c|c|c|c|c|c|c|c|c|c|c|}
\hline \multirow[b]{2}{*}{ Seed lot no. ${ }^{\mathrm{z}}$} & \multirow[b]{2}{*}{ County ${ }^{y}$} & \multirow[b]{2}{*}{ U.S. state ${ }^{\mathrm{x}}$} & \multirow[b]{2}{*}{ Total plants (no.) ${ }^{\mathrm{w}}$} & \multicolumn{7}{|c|}{ Seedlings for each disease rating (no.) ${ }^{\mathrm{w}, \mathrm{v}}$} \\
\hline & & & & Avg & 0 & 1 & 2 & 3 & 4 & 5 \\
\hline 11607 & Clarke & IA & 21 & 0 & 21 & 0 & 0 & 0 & 0 & 0 \\
\hline 11608 & Crosslake & $\mathrm{MN}$ & 3 & 0 & 3 & 0 & 0 & 0 & 0 & 0 \\
\hline 11610 & Mansfield & $\mathrm{OH}$ & 4 & 1.75 & 1 & 0 & 2 & 1 & 0 & 0 \\
\hline 11612 & East Moline & IL & 4 & 0 & 4 & 0 & 0 & 0 & 0 & 0 \\
\hline 11613 & Kansas City & MO & 24 & 0.08 & 23 & 0 & 1 & 0 & 0 & 0 \\
\hline
\end{tabular}

${ }^{\mathrm{z}}$ Seed lots received by cooperators were assigned numbers by the Rutgers University breeding program.

${ }^{\mathrm{y}}$ The county in which the $C$. americana seeds were collected.

${ }^{\mathrm{x}}$ The state in which the $C$. americana seeds were collected.

${ }^{\text {w}}$ Number of living seedlings at the Rutgers University Research and Extension Center in Cream Ridge, NJ.

${ }^{v}$ Disease ratings correspond to phenotypes: $0=$ no visible eastern filbert blight (EFB), $1=$ a single canker, $2=$ multiple cankers on a single branch, $3=$ multiple branches with cankers, $4=$ more than $50 \%$ of branches have cankers, and $5=$ all branches have cankers or the plant has died from EFB. 